\title{
Puffer Fish and its Consumption: To Eat or Not to Eat?
}

Inês Panão ${ }^{1}$, Conrado Carrascosa ${ }^{2}$, José Raduán Jaber ${ }^{3}$, António Raposo*1

${ }^{1}$ Centro de Investigação Interdisciplinar Egas Moniz, CiiEM, Instituto Superior de Ciências da Saúde Egas Moniz, ISCSEM, Quinta da Granja, Monte de Caparica, 2829-511 Caparica, Portugal.

${ }^{2}$ Department of Animal Pathology and Production, Bromatology and Food Technology, Faculty of Veterinary, Universidad de Las Palmas de Gran Canaria, Trasmontaña s/n, 35413 Arucas, Spain.

${ }^{3}$ Department of Morphology, Faculty of Veterinary, Universidad de Las Palmas de Gran Canaria, Trasmontaña s/n, 35413 Arucas, Spain.

Corresponding author: António Raposo, E-mail address: araposo@egasmoniz.edu.pt, Phone: $(+351) 918376093$

\begin{abstract}
This systematic review was done to examine the substantial increase in the number of intoxication cases in puffer fish associated with tetrodotoxin. In the past 5 years, 430 cases of intoxication and 52 deaths associated with puffer fish have been reported worldwide. It has also been verified that puffer fish have migrated to different regions, which has led to a negative environmental impact. Based on the information obtained herein, consumption of puffer fish should be legally limited, although it still remains very popular in several regions with negative social and economic impacts.
\end{abstract}

Keywords: puffer fish; tetrodotoxin; food safety; food-borne diseases; toxicity. 


\section{Introduction}

Nowadays, the fish industry is an international business whose global production is estimated at US\$ 232 billion in $2012^{(1)}$. Fisheries provide economic and nutritional benefits to people worldwide and are a major source of dietary animal protein ${ }^{(2)}$.

In recent years, marine fisheries have expanded and developed, with North America, Europe and Japan hosting the major fish industry companies. It is also believed that the demand for fishery resources will continue to increase while the world's population grows ${ }^{(3)}$. Certain types of fish may contain environmental contaminants that can cause food-borne diseases. The substantial increases in seafood consumption in recent years, together with the globalization of the seafood trade, have increased the potential exposure to these agents ${ }^{(4)}$. Certain organisms, such as California newts, goby fish, Australian octopus and Japanese gastropods, are known to contain toxins, and the risks associated with these seafood toxins are well-documented ${ }^{(5)}$. However, it is not possible to accurately estimate the number of food-borne disease incidences because several countries are not obliged to report these cases to the authorities, and because it is not possible to identify the food that caused the disease in most cases ${ }^{(5)}$.

The increase in food importations from countries such as China, Japan, Taiwan and Thailand, and migration and the consequent invasion of species into ecosystems that result from human activities has also contributed to increased poisoning incidences ${ }^{(5,6,7)}$. This scenario has occurred with puffer fish, which is typically consumed in Japan, where it is traditional food and considered a delicacy, even though it contains the potent neurotoxin tetrodotoxin (TTX), produced by ocean bacteria, which spreads through the food chain ${ }^{(7)}$, and is also found in other 
fish and gastropods ${ }^{(8)}$. The TTX concentration varies depending on species, time of the year and geographical location. Higher levels are found in the liver and ovaries, followed by the gut, skin and muscle ${ }^{(8,9)}$. There is no treatment for TTX poisoning, and prevention is the only means of avoiding the risks, and even potential death, associated with TTX poisoning ${ }^{(10,8)}$.

The first report on puffer fish poisoning was published before 1959 by the Japanese Ministry of Health and Wellness ${ }^{(11)}$. Since this report, several measures have been taken to prevent puffer fish intoxication. At the moment, it is well-established that this fish can be safely consumed if it is properly prepared to ensure that it is free of toxins. Unfortunately, cases of poisoning still occur and are mainly the result of improper processing, illegal sales and mixing puffer fish with other fish to make fish fillets. For these reasons, the consumption of puffer fish still remains controversial $^{(12,6)}$.

To date, it seems that no one has recently done a review to collect and analyze information on this important puffer fish-related topic. In order to fill this gap, the present study summarizes and organizes the main findings of recent research works on the number of puffer fish intoxication cases, consumption and TTX by means of a systematic review.

Even though TTX has been well-studied, cases of this poisoning still occur ${ }^{(13,14,15)}$. These findings demonstrate that even though legislative actions have been taken, it is still critical for people to be aware of the risks associated with consuming puffer fish. To assess whether consumption of puffer fish should be limited worldwide, as well as its risks and economic benefits, we reviewed several relevant studies and legal issues. 


\section{Puffer fish}

The puffer fish is a vertebrate animal that belongs to the class Actinopterygii, which includes the ray-finned fishes ${ }^{(16)}$. Puffer fishes are classified as Tetraodontiformes, which is the order that includes the following nine families: Balistidae (triggerfishes), Diodontidae (porcupinefishes), Molidae (molas), Monacanthidae (filefishes), Ostraciidae (boxfishes), Tetraodontidae (puffer fishes), Triacanthidae (triplespines), Triacanthodidae (spikefishes) and Tridontidae (threetoothed puffers). The families Diodontidae, Tetraodontidae and Triodontidae (185 species in 28 genera) include poisonous puffer fish, also known as tetrodotoxic fish ${ }^{(17,18)}$.

Puffer fish were first reported in $1914^{(19)}$. Because of their toxicity, this fish was not considered commercially valuable and was not extensively studied. Currently, this opinion has changed, and the number of puffer fish studies has increased for many reasons, including their known toxin (TTX) and their resistance to TTX toxicity ${ }^{(17)}$.

Regarding puffer fish toxicity, Arakawa et al. ${ }^{(13)}$ found that not all Diodontidae puffer fish contained TTX. The authors examined 23 species and found that two of these species (Lagocephalus gloveri and L. wheeleri), often used as ingredients in fish fillets, contained no toxic tissues. However, other species are highly toxic (L. lunaris, Takifugu oblongus and T. nihpbles) and have been reported to cause food poisoning in various countries, including Thailand ${ }^{(20,21)}$ Taiwan $^{(13)}$ Cambodia $^{(20,21,22)}$ and Bangladesh $^{(23,22)}$. TTX poisoning could result from cross-contamination caused by an inaccurate identification of these species ${ }^{(24,13)}$. For example, Lagocephalus lunaris contains a high level of TTX in muscle tissue and looks like other Lagocephalus spp. that are safe for consumption ${ }^{(17,24,13,25,26)}$. Nevertheless, a study ${ }^{(25)}$ on 
the toxicity of specific puffer fish species (L. spadiceus) collected from the waters of Sabah concluded that L. spadiceus is a nontoxic species because the toxin concentrations in muscle, liver and skin were less than $2 \mathrm{MU} / \mathrm{g}$ (MU is the amount of toxin required to kill a mouse (20 g) in 30 minutes). These results indicated that this toxin does not cause death at low concentrations ${ }^{(25)}$. In the same study, the authors were unable to determine the toxicity levels of L. lunaris and L. sceleratus, and further studies on these species are needed.

The toxicity levels of puffer fish are classified into the following four groups: less than 10 MU/g - nontoxic; 10-100 MU/g - slightly toxic; 100-1,000 MU/g - moderately toxic; above $1.000 \mathrm{MU} / \mathrm{g}$ - extremely toxic. Therefore, puffer fish with a toxicity level above $10 \mathrm{MU} / \mathrm{g}$ are considered unsafe for consumption following the recommendations of the Japanese health authorities ${ }^{(17)}$, where $10,000 \mathrm{MU}$ is the minimal lethal dose of TTX for humans.

The level of toxicity can vary within specific fish organs. The liver, ovaries, intestine and skin of puffer fish contain higher TTX concentrations than the muscle. For this reason, fish muscle is still available for consumption in specialized restaurants certified by the government (mainly in Japan, China, USA and Taiwan) ${ }^{(17,24,13,8)}$.

Puffer fish species are mainly tropical and have been found to inhabit all oceans worldwide, except those near the poles ${ }^{(17)}$. Most species inhabit the Pacific and Indian Oceans. The toxicity level of these fish varies drastically depending on the individual, region and season, and this finding indicates that a fish of a specific species may be poisonous in one location and nontoxic in another ${ }^{(27)}$. Therefore, a fish of a species known to be highly toxic may not necessarily be toxic. As mentioned above, the toxicity level of each species varies according to spawning season (in spring/summer, between May and July) ${ }^{(28)}$. During this season, most puffer fish are 
more toxic to protect their fertilized eggs. However, two species studied by $\mathrm{Yu}^{(17)}$ were seen to be less toxic during the spawning season. This finding could be a result of reduced activity of toxin-producing bacteria caused by a drop in seawater temperature, which occurs in winter. Furthermore, this seasonal trend in toxicity level does not apply to species such as L. wheeleri because its entire body is nontoxic throughout the year ${ }^{(13)}$.

Puffer fish are well known for their ability to swell like a balloon. This swelling occurs because of their ability to not only ingest a large amount of air or water into an expandable stomach, but to also alter their pectoral girdle and head. The shape change that accompanies inflation is possible because the ventral and lateral skin of these fish is extremely elastic and they have no ribs. This shape change is a defense mechanism against predators, which are unable to swallow inflated puffer fish and juvenile puffer fish are able to use this inflation mechanism ${ }^{(29)}$. Regarding puffer fish diet, fragments of coral, sponges, algae, molluscs and fish have been found in the stomachs and intestines of puffer fish, which indicates that most puffer fish species are omnivorous or herbivorous ${ }^{(17,30)}$. However, there is also evidence that some species are carnivorous, ${ }^{(31,32)}$ where diet is composed mainly of cephalopods (squids and cuttlefishes) and crustaceans (particularly crabs).

\subsection{Tetrodotoxin (TTX)}

TTX was named in 1909 by Japanese scientist Dr. Yoshizumi Tahara, and was long believed to be present only in puffer fish. However, Mosher et al. ${ }^{(33)}$ identified a toxin from the eggs of the California newt Taricha torosa as TTX. Then this same toxin was discovered in other organisms (Goby Yongeichthys criniger, atelopid frogs, the blue-ringed octopus Hapalochlaena 
maculosa, the carnivorous gastropod, Charonia sauliae, starfish of genus Astropecten, xanthid crabs, the horseshoe crab, Carcinoscorpius rotundicauda, flatworms, ribbon worms $)^{(34,35,36)}$. Since this discovery, several TTX derivatives have been found in various organisms ${ }^{(37)}$. TTX is a potent nonprotein low-molecular-weight $(319.3 \mathrm{Da})$ neurotoxin that inhibits the conduction of action potentials by blocking voltage-gated sodium channels in nerve/muscle membranes ${ }^{(13,26,38,39,40)}$. It is insoluble in organic solvents and water, stable under neutral and weakly acidic solutions, and is not degraded by cooking ${ }^{(13,26)}$. Despite knowledge of its toxicity, TTX was not isolated as a crystal until the early $1950 \mathrm{~s}^{(41)}$, and also chromatographically in the $1960 \mathrm{~s}^{(42,43)}$. The structure was not confirmed until several groups elucidated them to be independent of each other in the mid-1960s $\mathrm{s}^{(44,45,46)}$. Although the toxicity and pharmacology of TTX are well understood, much of the research conducted into the biogenesis of TTX is still speculative. TTX has a highly unusual structure that contains a single guanidinium moiety attached to a highly oxygenated carbon backbone. The carbon backbone of TTX consists of a 2,4- dioxaadamantane structure, decorated with 5 hydroxyl groups (Figure 1) ${ }^{(45,47)}$. The hydroxyl groups on the fused ring systems increase the ability to react in aqueous environments. This toxin is odorless and heat stable but unstable at $\mathrm{pH}$ levels above 8.5 and below $3.0^{(48)}$.

Several groups have synthesized TTX (Figure 2) using glucose as a precursor molecule ${ }^{(50,51)}$. The key intermediate compound for the synthesis of TTX can be obtained from either quinone ${ }^{(50)}$ or carbohydrate $^{(49)}$. Ohyabu et al. ${ }^{(52)}$ achieved the asymmetric synthesis of tetrodotoxin from 2acetoxy-tri-O-acetyl-D-glucal. However, in general, the chemical synthesis of TTX involves many complex steps (average $\mathrm{N}=23-67)$, which generate low yields $(0.34-1.82 \%)$ of the target compound $^{(52)}$. Additionally in most syntheses, it is necessary to develop methods for purification. 
These complications make most laboratory synthesis approaches for TTX and its analogs unfeasible for commercial scale-up ${ }^{(54)}$.

The biosynthetic origin of TTX in vivo has yet to be confirmed. It is assumed that arginine is the precursor moiety for TTX production within the organism (Figure 3$)^{(53,55)}$. A likely biosynthetic route to TTX incorporates arginine and either a C5 branched sugar or an alkyl precursor ${ }^{(54)}$. Isolation of deoxy-TTX pathway precursors and intermediates $(53,55,56)$ suggests that TTX biosynthesis may consist of multiple oxidation steps, which thus supports the oxidation of alkyl precursors rather than the incorporation of a sugar-derived moiety. Yet according to Kellmann et $a l .,{ }^{(57)}$ if arginine is indeed a substrate for TTX biosynthesis, an amidinotransferase enzyme may be implicated, similarly to that involved in saxitoxin biosynthesis. Nevertheless to date, no biosynthesis enzymes involved in TTX production have been isolated from any TTX-producing $\operatorname{organism}^{(58)}$.

Regarding the etiology of TTX, several theories for the formation and bio-transfer of TTX have been proposed. TTX is believed to bio-accumulate via the marine food chain ${ }^{(59)}$, and its origin in TTX-bearing animals has been pursued for a long time. Marine bacteria $V$. alginolyticus, Vibrio VIII, Vibrio I, S. alga, Alteromonas tetrodonis, and others, have been shown to produce TTX, although the amount of TTX is small. Carnivores, omnivores, detritus feeders and scavengers are postulated to be intoxicated with TTX through their food chain or along with parasitism and symbiosis. This mechanism is repeated many times and leads to the accumulation of TTX in high concentrations in species at upper levels of the food chain. Finally, puffer fish at the top of the food chain are intoxicated with TTX by feeding on the TTX-bearing organisms lower in the food chain (Figure 4$)^{(60)}$. It is known that several species of bacteria and other microorganisms often 
live within larger marine animals in an assumed or in an established mutually advantageous symbiosis ${ }^{(61,62)}$. The following bacteria species are known TTX producers and have been isolated from various marine organisms: Vibrio alginolyticus from starfish, Astropecten polyacanthus ${ }^{(63)}$; Vibrio spp. from the puffer fish, Fugu vermicularis radiates ${ }^{(64)}$; Aeromonas from puffer fish, Takifugu obscures ${ }^{(65)}$; Vibrio and Pseudomonas spp. from gastropod, Niotha Clathrata $^{(66)}$. Chau et al. ${ }^{(53)}$ have provided a comprehensive account of the distribution of TTXproducing bacteria in many organisms. Despite these studies, the exact origin and pathway for the synthesis and bio-transfer of TTX are not yet fully known and require further investigation ${ }^{(54)}$. Unravelling the biosynthesis of tetrodotoxin will no doubt lead to a better understanding of natural product toxin assembly in marine microorganisms as well as to the genetic regulation of the toxin biosynthesis ${ }^{(57)}$.

It has been proposed that the animals that belong to higher phylogenetic series are more intolerant to TTX than animals of lower series because they are extremely dependent on their central nervous system ${ }^{(67,68,69)}$. Therefore, higher forms of animals and humans are more sensitive to TTX, which can be toxic at extremely low concentrations ${ }^{(70)}$. The minimum lethal dose for humans is $2 \mathrm{mg}^{(71,72,73,26,74)}$. Currently, there is no antidote or treatment for TTX poisoning. Only symptomatic and supportive care is currently available, and it is essential that the poison is removed from the body as quickly as possible (typically by gastric lavage). Although a monoclonal anti-TTX antibody was recently developed and used as a chemical tool, it had little effect in the clinical setting ${ }^{(75)}$. Treatment with sodium bicarbonate solutions and anticholinesterase drugs, such as edrophonium and neostigmine, has been recommended to attenuate the effects of $\mathrm{TTX}^{(17,13)}$. 
The typical symptoms of TTX poisoning are numbness of lips, tongue and limbs, paresthesia (a neurosensitive disorder), dysarthria (difficulty in speaking due to a malfunction of the motor organs responsible for phonation), respiratory distress, and death resulting from respiratory failure $^{(76)}$. If a patient survives after the first 24 hours of TTX poisoning, then the prognosis for complete recovery is good and further complications should not arise ${ }^{(17,13)}$.

TTX has been extensively studied to better understand the toxin responsible for its toxicity and to prevent the damage that its ingestion may cause ${ }^{(13)}$. Some researchers ${ }^{(17,18,13,26)}$ have argued that TTX is not produced by puffer fish, but by marine bacteria. Therefore, when puffer fish is placed in an environment where these bacteria do not exist, there is no evidence that fish contain the toxin. This finding suggests that puffer fish do not synthesis TTX, but accumulate it through the food chain. To elucidate this process, Arakawa et al. ${ }^{(13)}$ conducted a study that demonstrated that when fish ingested TTX, it was transferred to proteins in specific places in the organism for storage. However, puffer fish have glands in their skin that produce TTX if it is stimulated externally. Based on this finding, some researchers have argued that TTX is a defense chemical ${ }^{(77,78,79)}$.

In a study conducted by Ji et al. ${ }^{(28)}$, it was concluded that the mechanism by which TTX accumulates in puffer fish is affected by the season of the year and environmental stimuli, and that wild puffer fish are more likely to accumulate toxins than cultured puffer fish. Both Oliveira et al. ${ }^{(18)}$ and Auawithoothij \& Noomhorm ${ }^{(26)}$ concluded that TTX is not produced by puffer fish, but is either obtained from the food chain or produced by microorganisms that live in symbiosis with the fish. $\mathrm{Yu}^{(17)}$ also concluded that TTX can be produced endogenously as a control substance to protect fish and their eggs from predators. 
It is difficult to detect the origin of the microorganisms that live in symbiosis with puffer fish because they are highly diverse. The study by Yang et al ${ }^{(80)}$ identified 12 species of bacteria. It has been predicted that diet would affect the bacterial composition found in the intestines of these fish, but no dietary effects were observed in skin and other TTX-accumulating organs in the above study ${ }^{(80)}$. Furthermore, it has been well-established that bacterial flora varies according to the aquatic environment. Unlike other researchers, Yang et al. ${ }^{(80)}$ concluded that ingesting TTX through the food chain does not affect the TTX content of puffer fish.

Vibrio alginolyticus, Shewanella putrefaciens, Micrococcus spp. and Bacillus spp. are the major TTX-producing bacteria $^{(26)}$. TTX accumulation in puffer fish can occur via these two mechanisms: the TTX produced by microorganisms is assimilated by the intestines, passes into the blood circulatory system and, consequently, accumulates in internal organs, muscle and skin of fish ${ }^{(26)}$; or growth of bacteria depends on environmental conditions, such as temperature and salinity, which affects the amount of TTX that accumulates through food ingestion ${ }^{(26)}$. It has been reported that the TTX levels in puffer fish tissues are higher from February to March, and then from August to October ${ }^{(26)}$.

Shewanella putrefaciens is one of the predominant microorganisms to be isolated from internal organs of the puffer fish L. lunaris. A work by Auawithoothij \& Noomhorm ${ }^{(26)}$ has reported that its growth rate is slow at low temperatures, but its TTX-production rate is high, and this production rate is responsible for the higher toxicity level observed in L. lunaris from January to March (when the seawater temperature is low). These rates inversely change from May to June and from September to October (when seawater temperatures are higher). This same study also 
investigated the effect of salinity, which was found to affect only TTX production, which increased when the salinity level was low $(9 \text { and } 22 \mathrm{ppt})^{(26)}$.

Thus, if the bacterial content is high in puffer fish, it is likely that the habitat and food chain contain high TTX levels, which will result in a high TTX accumulation rate in puffer fish ${ }^{(26)}$. Saoudi et al. ${ }^{(8)}$ proposed that the amount of TTX obtained though the food chain is not sufficient to cause human intoxication. Therefore, TTX may also be synthesized by puffer fish.

Despite these discrepancies among researchers, there is a consensus that the organs of puffer fish contain TTX, but do not appear to be affected by it. So, they must have a TTX resistance mechanism that involves substituting an aromatic amino acid in the voltage-gated sodium channel, which is sensitive to the toxin, for a nonaromatic amino acid with a very low affinity to the toxin ${ }^{(13)}$. Penzotti et al. ${ }^{(81)}$ proposed that this resistance mechanism could result from a mutation in the protein sequence of the voltage-gated sodium channel.

As TTX selectively blocks the voltage-gated sodium channel, it has been used as an analgesic to treat various disorders, such as asthma, rheumatism, pruritus, impotence, enuresis, tetanus, pertussis, headaches and cancer ${ }^{(17)}$. TTX is also an effective muscle relaxant in patients with disorders characterized by convulsions, and it acts as a neuroprotective drug in the treatment of post-stroke ischaemic brain damage ${ }^{(17)}$. El-Dayem et al. ${ }^{(82)}$ analyzed the antitumor activity of TTX on Ehrlich ascites carcinomas and observed a noticeable effect with TTX treatment, which was similar to that observed in cells of the nervous system. This effect could be the result of its antioxidant activity as TTX contains guanidinum moiety that has a negative charge and can act as free radicals. 
TTX is mostly associated with puffer fish. However, it is important to remember that many other species also contain this toxin, including other seafood species, and its concentration level in other species depends on many different environmental factors. Thus further studies and cooperation among countries, especially Asian nations, are necessary to minimize the risk associated with $\mathrm{TTX}^{(13)}$.

\subsection{World consumption and associated risks}

The risks associated with ingesting TTX due to the neurological damage that can produce potential death (resulting from respiratory failure) have been well-documented. For these reasons, the sale and consumption of puffer fish must be controlled ${ }^{(17)}$.

The majority of cases of TTX poisoning and related deaths occur in Japan, China and Taiwan, where puffer fish are traditionally consumed and considered a delicacy ${ }^{(17,83)}$. In this case, it is important to note that some of these cases are due to the consumption of other animals, such as gastropods and goby ${ }^{(83)}$. In Brazil, puffer fish are sporadically consumed by local populations, and some cases of TTX poisoning have been reported ${ }^{(18)}$. Some cases have also been reported in countries like Singapore, Thailand, Hong Kong, Malaysia, Bangladesh, Papua New Guinea, Australia, Hawaii, Europe and Haiti ${ }^{(17)}$. However, as a result of the agreement reached between Japanese and US Governments on importing puffer fish, intoxication cases and resulting damage are $\operatorname{rare}^{(24,84)}$.

It is widely accepted that cultured puffer fish are less toxic than their wild counterparts because their TTX content is much lower. In Japan, some puffer fish organs, such as the liver, are considered delicious. The liver is rich in unsaturated fatty acids. Moreover, puffer fish liver 
oil can be extracted and used as a pharmaceutical drug. While this practice is common in China, more studies are needed to ensure that the extracted oil is free of toxins ${ }^{(17,24,28)}$.

Recent reports have emphasized that puffer-fish intoxications continue to occur despite the measures taken by the Japanese Government ${ }^{(13)}$. This information suggests that more efforts are needed to educate people about the risks associated with consuming this fish.

In a study by Monaliza \& Samsur ${ }^{(25)}$, the puffer fish Lagocephalus spadiceus was categorized as nontoxic because it exhibited very low scores of toxin extracted from muscle, liver and skin (less than $2 \mathrm{MU} / \mathrm{g}$ ). This finding suggests that this species can be safely consumed. However, these authors were unable to determine the toxicity levels of the two other species (Lagocephalus lunaris and Lagocephalus sceleratus) analyzed in their study; therefore, more studies on the toxicity of these species are needed. Saoudi et al. ${ }^{(8)}$ concluded that raw or cooked fish, including muscle (Lagocephalus lagocephalus), has toxic effects on the human liver and kidneys, and that its consumption should be avoided, even though it is currently allowed ${ }^{(13,25,8)}$.

Mohd Nor Azman \& Wan Norhana ${ }^{(85)}$ studied the TTX content in dried salted yellow puffer fish eggs obtained at a market in Kuching (Sarawak, Malaysia). They found that these products were readily available, even though the local people were aware of the toxicity that yellow puffer fish and its salted eggs may entail. The greatest danger of eating these eggs lies in them containing the highest TTX concentration level of any puffer fish products, and TTX should be completely removed from eggs before being consumed. The toxicity of ovaries is higher when ovules are maturing. Anraku et al. ${ }^{(9)}$ studied the TTX concentration levels in fermented ovary products sold in markets to discover that if ovaries were salted and fermented over a long period of time, the 
toxin content level lowered because the electric current inhibiting its release increased. This finding indicates that this preparation process enables safe consumption of puffer fish ovaries ${ }^{(85)}$. The different conclusions reached by these various authors could result from the different methods used in their studies. Despite these differences, all these authors ${ }^{(25,9,85)}$ suggested that the muscle tissue can be safely consumed as long as it is prepared according to the set standards. According to Japanese food-safety standards ${ }^{(86)}$, puffer fish with a toxicity level below $10 \mathrm{MU} / \mathrm{g}$ are considered safe for human consumption. In addition, puffer fish consumption is allowed only if it is prepared and cooked by a highly trained chef who has passed the necessary examination and has obtained a license to cook puffer fish. The Japanese Government has also taken other measures to prevent puffer fish intoxication, such as publishing posters to raise communal awareness about poisonous puffer fish species ${ }^{(17,7)}$.

Despite the efforts made by the authorities to prevent TTX poisoning cases, they continue to occur, as shown in Figure 5, which lists the world regions where poisoning cases associated with puffer fish consumption have been reported since $2008^{(36,87,24,13,15,88,89,90)}$. Table 1 places emphasis on the studies conducted in the last 5 years, which cumulatively report 430 cases of intoxication and 52 deaths associated with puffer fish. The most serious cases occurred recently, with 141 intoxications and 17 deaths in Bangladesh in 2011, and 192 intoxications which resulted in 22 deaths in Taiwan in 2012. Since 1995, several intoxications and related deaths have been reported in different countries ${ }^{(91,95,98,88,81)}$. These findings suggest that illegal imports of puffer fish and consumers preparing these fish at home still occur because people may be unaware of the associated risks. These findings also show that TTX poisoning frequently results 
from the cross-contamination of muscle caused by inadequate preparation or that puffer fish is sometimes sold under another name, such as monkfish ${ }^{(17,24,28)}$.

\subsection{Legislation}

In Japan, where the consumption of this fish is a tradition, the government has taken several measures, one of which is that all cases of puffer fish poisoning must be reported ${ }^{(12,7,84)}$. The Japanese Ministry of Health, Labour and Welfare published guidelines for edible puffer fish in $1983^{(13)}$ to lower the frequency of TTX poisoning cases due to puffer fish consumption. Since they were published, the number of accidents in specialty restaurants have almost been eradicated, but many cases of such poisoning continue to occur because people eat home-made dishes that contain toxic portions of fish, such as liver and ovaries, after catching puffer fish recreationally ${ }^{(13)}$. In addition, other governments have banned puffer fish consumption. Therefore, according to Annex III of Regulation 854/2004 of the European Parliament and Council, it is forbidden to sell fish belonging to the Tetraodontidae family in the European Community ${ }^{(101)}$.

The importation of puffer fish into the United States is regulated by the U.S. Food and Drug Administration (FDA). An agreement was reached between the Japanese Ministry of Health and Welfare and the FDA in 1989, which permits the USA to import puffer fish and their different portions (meat, skin, and testicles). The imported product can be sold only to restaurants that belong to the Torafugu Buyers Association, and restaurant operators are not

allowed to transfer or resell the imported product to any other commercial establishments ${ }^{(24)}$. As a result of this agreement, no TTX intoxications have been reported in the USA because no 
legally sold product has contained dangerous levels of this toxin ${ }^{(24)}$. When puffer fish are imported beyond the terms of this contract, according to the FDA ${ }^{(84)}$, detention with no physical examination of puffer fish and products containing this fish is allowed ${ }^{(24)}$.

Puffer fish have also been found outside the Indian and Pacific Oceans because of new migration patterns resulting from human activities. For example, the opening of the Suez Canal, global warming and the tropicalization process have led puffer fish to arrive in the Mediterranean Sea ${ }^{(7)}$. This finding indicates that the development of analytical methods to distinguish fish specimens is needed, which would be an important epidemiological tool for determining the geographical range and variety of the species carrying marine toxins, and would improve the FDA's ability to prevent illegal imports of toxic fish. In addition, due to negative environmental impact changes, which have a negative environmental impact because they alter ecosystems, new measures should apply to improve the enforcement of rules and laws to protect people ${ }^{(24,102,7)}$.

\subsection{Economic and social impacts}

Fisheries play an important role in ensuring a stable supply of fish, as well as providing income and employment opportunities, promoting foreign exchange, and preserving marine

environments and traditional marine cultures ${ }^{(102)}$. Therefore, the safety of fish products is very important to strike a balance between the country's economy and the highest possible export $\operatorname{rates}^{(103)}$.

The management and control of food-borne diseases involve various sectors and organizations. Moreover, food globalization has increased the demand for fish and exposed different 
populations to exotic foods and pathogens. So measures must be taken to ensure consumer food safety ${ }^{(104)}$.

Studies on puffer fish, TTX and its toxicity are essential for governments and organizations to reduce the risks associated with its consumption through laws and procedures on capturing and preparing puffer fish. Thus in recent years, consumers are better educated on various topics related to food hygiene and safety, which has had a strong impact on the food industry $(24,102,7)$. The costs associated with investigating food-borne outbreaks, their treatment, cost to employers and food industry losses could result in lowering both sale rates and stock prices ${ }^{(76)}$.

The three major hosts of fish markets are the European Union, North America and Japan; therefore, it is essential that these countries maintain rigorous food hygiene and safety standards because their actions in this area have profound economic and social impacts worldwide ${ }^{(105)}$. Therefore, countries like Japan undertake very important aquaculture activity that has become an outstanding economic growth sector for food production, and particularly in puffer fish ${ }^{(103)}$. The persistence of puffer fish poisoning cases indicates that there is a need for more stringent regulations on puffer fish imports by government agencies that control food, such as the FDA, and also for more public awareness and education on the dangers of puffer fish consumption ${ }^{(24)}$.

\section{Conclusions}

As the world population grows, the fish consumption rate will continue to rise ${ }^{(3)}$. Therefore, it is important to establish educational measures to warn the public about the risks associated with certain fish consumption ${ }^{(5)}$. 
Relevant publications ${ }^{(17,18,13,8,26,9)}$ concur that puffer fish are not the only species to contain TTX, which varies according to species, geographic location and season of the year. This fluctuation in toxicity levels supports the idea that the toxicity of these fish is strongly related to bacteria and to other organisms that live in symbiosis with fish. The TTX-producing bacteria reported so far inhabit generally in the intestine of all kinds of fish and probably produce only very small amounts of TTX to intoxicate them. So, the TTX intoxication mechanism of puffer fish will progress, starting from the primary production of TTX by its producing bacteria, followed by a condensed TTX concentration in several other steps of the food chain.

Some fish parts, such as the liver and ovaries, contain the highest TTX concentrations which are unfit for human consumption. In contrast, puffer fish muscle can be safely consumed because its toxin content level is negligible. Therefore, several reports have demonstrated that puffer fish muscle can be safely consumed provided it is prepared according to the aforementioned standards ${ }^{(18,21,13,8)}$.

Despite the number of studies conducted on puffer fish toxicity, there is no cure or antidote for TTX poisoning ${ }^{(17,13)}$, and the current treatment method includes removing the toxin from the body by gastric lavage. It has been well-established that TTX is a dangerous neurotoxin, and despite all government efforts to prevent puffer fish intoxication, it still occurs, mainly because of its illegal sale and home preparation ${ }^{(17,24,28)}$. It is important to note, however, that TTX appears to be of medicinal value, but more studies are needed to fully understand its medicinal uses ${ }^{(17,81)}$.

As a result of a tropicalization process, puffer fish have migrated to global regions where it was not previously found. Therefore, it is even more important that legal and educational 
measures are taken, such as developing new methods for identifying, monitoring, and assessing the origin of and the risks associated with puffer fish, and educating the public on proper food safety at home to prevent TTX poisoning ${ }^{(104,106)}$.

Collaborations among poison-control centers, local and state health departments and federal agencies are essential to efficiently detect and respond to cases of food-borne toxin ingestion, and other threats to the food supply. Collaborations between federal agencies and academic institutions are also important because they provide agencies access to the latest analytical techniques that can be used to improve regulatory compliance ${ }^{(24)}$.

Based on the information provided in this evaluation, puffer fish consumption should be legally limited, even though it is still very popular in certain regions.

\section{Conflict of interest}

The authors declare there are no conflicts of interest.

\section{Acknowledgements}

The authors thank Egas Moniz - Cooperativa de Ensino Superior, CRL for all the support provided. 


\section{References}

1. Carlucci, D.; Nocella, G.; De Devitiis, B.; Viscecchia, R.,; Bimbo, F.; Nardone, G. Consumer purchasing behaviour towards fish and seafood products. Patterns and insights from a sample of international studies. Appetite, 2015. 84, 212-227

2. Food and Agriculture Organization (FAO). Developing new approaches to global stock status assessment and fishery production potential of the seas (p. 1). 2014. Rome.

3. Swartz, W.; Sala, E.; Tracey, S.; Watson, R.; Pauly, D. The spatial expansion and ecological footprint of fisheries (1950 to present). PloS One, 2010. 5(12), e15143.

4. Sobel, J.; Painter, J. Illnesses Caused by Marine Toxins. Food Safety. Clin. Infect. 2005. Dis. 41, 1290-1296.

5. Upton, H. F. Seafood Safety: Background and Issues. Retrieved from http://www.fas.org/sgp/crs/misc/RS22797.pdf. 2010.

6. Chulanetra, M.; Sookrung, N.; Srimanote, P.; Indrawattana, N.; Thanongsaksrikul, J.; Sakolvaree, Y.; Chaicumpa, W. Toxic marine puffer fish in Thailand seas and tetrodotoxin they contained. Toxins, 2011, 3 (10), 1249-62.

7. Nader, M. R.; Indary, S.; Boustany, L. E. The puffer fish Lagocephalus sceleratus (gmelin, 1789) in the eastern mediterranean. Athens. Retrieved from http://www.fao.org/docrep/field/009/ap967e/ap967e.pdf. 2012.

8. Saoudi, M.; Messarah, M.; Boumendjel, A.; Abdelmouleh, A.; Kammoun, W.; Jamoussi, K.; El Feki, A. Extracted tetrodotoxin from puffer fish Lagocephalus lagocephalus induced 
hepatotoxicity and nephrotoxicity to Wistar rats. African Journal of Biotechnology, 2011, 10(41), 8140-8145.

9. Anraku, K.,; Nonaka, K.; Yamaga, T.; Yamamoto, T.; Shin, M.; Wakita, M.; Akaike, N. Removal of toxin (tetrodotoxin) from puffer ovary by traditional fermentation. Toxins, 2013, 5(1), 193-202.

10. Huss, H.; H., Ababouch, L.; Gram, L. Assessment and management of seafood safety and quality. FAO Fisheries Technical Paper. 2004.

11. LINFO.RE. Intoxication alimentaire : les 10 patients sortis d'affaire. Retrieved March 20, 2014, from http://www.linfo.re/Ile-de-la-Reunion/Sante/547785-Intoxication-alimentaire-les-10patients-sortis-d-affaire

12. Food and Drug Administration (FDA). FDA Provides Advice on Safe Sources of Puffer Fish. Office of the Commissioner. 2007. Retrieved from http://www.fda.gov/newsevents/newsroom/pressannouncements/2007/ucm109011.htm

13. Arakawa, O.; Hwang, D.-F.; Taniyama, S.;Takayani, T. Toxins of Pufferfish That Cause Human Intoxications. Coastal Environmental and Ecosystem Issues of the East China Sea. TERRAPUB. $\quad$ 2010, $\quad$ Retrieved from $\quad$ http://naosite.lb.nagasakiu.ac.jp/dspace/handle/10069/23514

14. Ferreira, T. R.; Corrêa, I. R. dos S.; Hoshino, S. do S. N.; da Silva, C. L. Q.; Pardal, P. P. de O. Envenomation caused by the consumption of pufferfish liver. Revista paraense de medicina. 2010. Retrieved from http:/files.bvs.br/upload/S/0101-5907/2010/v24n3-4/a2367.pdf 
15. Homaira, N.; Rahman, M.; Luby, S. P.; Rahman, M.; Haider, M. S.; Faruque, L. I.; Gurley, E. S. Multiple outbreaks of puffer fish intoxication in Bangladesh, 2008. The American Journal of Tropical Medicine and Hygiene, 2010, 83 (2), 440-4.

16. Nelson, J. S. Fishes of the World. 1994. (I. John Wiley and Sons, Ed.) ( $3^{\mathrm{a}}$ ed.). New York.

17. Yu, C. A comprehensive study of the Hong Kong puffer fishes and their toxins. The Hong $\begin{array}{lllll}\text { Kong Polytechnic } & \text { University. } & \mathbf{2 0 0 3} & \text { Retrieved }\end{array}$ http://repository.lib.polyu.edu.hk/jspui/handle/10397/2165

18. Oliveira, J. S., Fernandes, S. C. R., Schwartz, C. A., Bloch, C., Melo, J. A. T., Rodrigues Pires, O., \& de Freitas, J. C. Toxicity and toxin identification in Colomesus asellus, an Amazonian (Brazil) freshwater puffer fish. Toxicon: Official Journal of the International Society on Toxinology, 2006, 48(1), 55-63.

19. Seale, A. Fishes of Hong Kong. The Philippine Journal of Science, 1914, 9, 59-83.

20. Brillantes, S., W. Samosorn, S. Faknoi and Y. Oshima. Toxicity of puffers landed and marketed in Thailand. Fisheries Science, 2003, 69, 1224-1230.

21. Ngy, L., C.F. Yu, S. Taniyama, T. Takatani and O. Arakawa. Co-occurrence of tetrodotoxin and saxitoxin in Cambodian marine pufferfish Takifugu oblongus. African Journal of Marine Science, 2009, 31, 349-354.

22. Ngy, L., S. Taniyama, K. Shibano, C.F. Yu, T. Takatani and O. Arakawa. Distribution of tetrodotoxin in pufferfish collected from coastal water of Sihanouk Ville, Cambodia. Journal of the Food Hygienic Society of Japan, 2008, 49, 361-365. 
23. Mahmud, Y., M.B. Tanu and T. Noguchi. First occurrence of a food poisoning incident due to ingestion of Takifugu oblongus, along with a toxicological report on three marine puffer species in Bangladesh. Journal of the Food Hygienic Society of Japan, 1999, 40, 473-480.

24. Cohen, N. J.; Deeds, J. R.; Wong, E. S.; Hanner, R. H.; Yancy, H. F.; White, K. D.; Gerber, S. I.; Public health response to puffer fish (Tetrodotoxin) poisoning from mislabeled product. Journal of Food Protection, 2009, 72 (4), 810-7.

25. Monaliza, M.; Samsur, M. Toxicity and Toxin Properties Study of Puffer Fish Collected from Sabah Waters. Health and the Environment Journal, 2011, 2 (1), 14-17.

26. Auawithoothij, W.; Noomhorm, A. Shewanella putrefaciens, a major microbial species related to tetrodotoxin (TTX)-accumulation of puffer fish Lagocephalus lunaris. Journal of Applied Microbiology, 2012, 113(2), 459-65.

27. Noguchi, T.; Ebesu, J. S.. Puffer poisoning: epidemiology and treatment. Toxin Reviews, 2001, 20(1), 1-10.

28. Ji, Y.; Liu, Y.; Gong, Q.-L.; Zhou, L.; Wang, Z.-P. Toxicity of cultured puffer fish and seasonal variations in China. Aquaculture Research, 2011, 42 (8), 1186-1195.

29. Krumme, U.; Keuthen, H.; Saint-Paul, U.; Villwock, W. Contribution to the feeding ecology of the banded puffer fish Colomesus psittacus (Tetraodontidae) in north Brazilian mangrove creeks. Brazilian Journal of Biology, 2007, 67(3), 383-392.

30. Begossi, A. Food Taboos at Buzios Island (Brazil): Their Significance and Relation to Folk Medicine. J. Ethnobiol, 1992, 12(1): 117-139. 
31. Lim, S.; Kim, S.; Ko, G.; Song, J.; Oh, D.; Kim, J.; Kim, J.; Lee, K. Fish meal replacement by soybean meal in diets for Tiger puffer, Takifugu rubripes. Aquaculture, 2011, 313: 165-170.

32. Aydin, M. Growth, Reproduction and Diet of Pufferfish (Lagocephalus sceleratus Gmelin, 1789) from Turkey's Mediterranean Sea Coast. Turkish Journal of Fisheries and Aquatic Sciences, 2011, 11: 569-576

33. Mosher, H.S., G.J. Fuhrman, F.A. Fuhrman and H.G. Fischer. Tarichatoxin-tetrodotoxin, a potent neurotoxin. Science, 1965, 144, 1100-1110.

34. Miyazawa, K. and T. Noguchi. Distribution and origin of tetrodotoxin. Journal of Toxicology-Toxin Reviews, 2001, 20, 11-33.

35. Hwang, D.F. and T. Noguchi. Tetrodotoxin poisoning. Advances in Food and Nutrition Research, 2007, 52, 141-236

36. Noguchi, T.; Arakawa, O. Tetrodotoxin - distribution and accumulation in aquatic organisms, and cases of human intoxication. Marine Drugs, 2008, 6(2), 220-42.

37. Yotsu-Yamashita, M. Chemistry of puffer fish toxin. Journal of Toxicology-Toxin Reviews, 2001, 20, 51-66.

38. Narahasi, T. Pharmacology of tetrodotoxin. J. Toxicol, Toxin Rev., 2001, 20, 67-84.

39. Fozzard, H.A.; Lipkind, G.M. The tetrodotoxin binding site is within the outer vestibule of the sodium channel. Marine Drugs, 2010, 8, 219-234. 
40. Chulanetra, M.; Bangphoomi, K.; Sookrung, N.; Thanongsaksrikul, J.; Srimanote, P.; Sakolvarvaree, Y.; Choowongkomon, K.; Chaicumpa, W. Human ScFv that block sodium ion channel activity of tetrodotoxin. Toxicon, 2012, 59, 272-282.

41. Yokoo, A. Study on chemical purification of tetrodotoxin (3)—purification of spheroidine. J. Chem. Soc. Japan, 1950. 71, 590-592.

42. Brown, M. S.; Mosher, H. S. Tarichatoxin: Isolation and purification. Science, 1963, 140, 295-296.

43. Fuhrman, F. Tetrodotoxin, tarichatoxin, and chiriquitoxin: Historical perspectives. Ann. N. Y. Acad. Sci, 1986, 479, 1-14.

44. Goto, T.; Kishi, Y.; Takahashi, S.; Hirata, Y. Tetrodotoxin. Tetrahedron, 1965, 21, 20592088.

45. Tsuda, K.; Ikuma, S.; Kawamura, M.; Tachikawa, R., Sakai, K. Tetrodotoxin. VII. On the structure of tetrodotoxin and its derivatives. Chem. Pharm. Bull, 1964, 12, 1356-1374.

46. Woodward, R.; Gougoutas, J. The structure of tetrodotoxin. J. Am. Chem. Soc., 1964, 86, $5030-15030$.

47. Woodward, R.B. The structure of tetrodotoxin. Pure Appl. Chem., 1964, 9, 49-74.

48. Mosher, H.S. The chemistry of tetrodotoxin. Annals of the New York Academy of Sciences, 1986, 479, 32-43. 
49. Sato, K.; Akai, S.; Shoji, H.; Sugita, N.; Yoshida, S.; Nagai, Y.; Suzuki, K.; Nakamura, Y.; Kajihara, Y.; Funabashi, M.; et al. Stereoselective and efficient total synthesis of optically active tetrodotoxin from d-Glucose. J. Org. Chem., 2008, 73, 1234-1242.

50. Kishi, Y.; Aratani, M.; Fukuyama, T.; Nakatsubo, F.; Goto, T.; Inoue, S.; Tanino, H.; Sugiura, S.; Kakoi, H. Synthetic studies on tetrodotoxin and related compounds. III. Stereospecific synthesis of an equivalent of acetylated tetrodamine. J. Am. Chem. Soc. 1972, 94, 9217-9219.

51. Adachi, M.; Imazu, T.; Isobe, M.; Nishikawa, T. An improved synthesis of (-)-5,11dideoxytetrodotoxin. J. Org. Chem., 2013, 78, 1699-1705.514.

52. Ohyabu, N.; Nishikawa, T.; Isobe, M. First asymmetric total synthesis of tetrodotoxin. J. Am.Chem. Soc., 2003, 125, 8798-8805.

53. Chau, R.; Kalaitzis, J.A.; Neilan, B.A. On the origins and biosynthesis of tetrodotoxin. Aquat. Toxicol., 2011, 104, 61-72.

54. Bane, V.; Lehane, M.; Dikshit, M.; O’Riordan, A.; Furey, A. Tetrodotoxin: Chemistry, Toxicity, Source, Distribution and detection. Toxins, 2014, 6, 693-755

55. Kotaki, Y.; Shimizu, Y. 1-Hydroxy-5,11-dideoxytetrodotoxin, the first N-hydroxy and ringdeoxy derivative of tetrodotoxin found in the newt Taricha granulosa. J. Am. Chem. Soc., 1993, $115,827-830$.

56. Yotsu-Yamashita, M., Schimmele, B., Yasumoto, T. Isolation and structural assignment of 5 deoxytetrodotoxin from the puffer fish Fugu poecilonotus. Bioscience, Biotechnology, and Biochemistry, 1999, 63, 961-963. 
57. Kellmann, R., Mihali, T.K., Jeon, Y.J., Pickford, R., Pomati, F., Neilan, B.A. Biosynthetic intermediate analysis and functional homology reveal a saxitoxin gene cluster in cyanobacteria. Applied and Environmental Microbiology, 2008, 74, 4044-4053.

58. Kalaitzis, J. A., Chau, R., Kohli, G. S., Murray, S. A., \& Neilan, B. A. Biosynthesis of toxic naturally-occurring seafood contaminants. Toxicon, 2010, 56(2), 244-258.

59. Williams, B.L. Behavioral and chemical ecology of marine organisms with respect to tetrodotoxin. Marine Drugs, 2010, 8, 381-398.

60. Noguchi, T.; Arakawa, O.; Takatani, T. TTX accumulation in pufferfish. Comp. Biochem.Physiol. D., 2006, 1, 145-152.

61. Childress, J.J.; Fisher, C.R.; Brooks, J.M.; Kennicutt, M.C.; Bidigare, R.; Anderson, A.E. A methanotrophic marine molluscan (Bivalvia, Mytilidae) symbiosis: Mussels fueled by gas. Science 1986, 233, 1306-1308.

62. Dubilier, N.; Bergin, C.; Lott, C. Symbiotic diversity in marine animals: The art of harnessing chemosynthesis. Nat. Rev. Microbiol., 2008, 6, 725-740.

63. Narita, H.; Matsubara, S.; Miwa, N.; Akahane, S.; Murakami, M.; Goto, T.; Nara, M.; Noguchi, T.; Saito, T.; Shida, Y. Vibrio alginolyticus, a TTX-producing bacterium isolated from the starfish Astropecten polyacanthus. Nippon Suisan Gakk., 1987, 53, 617-621.

64. Lee, M.-J.; Jeong, D.-Y.; Kim, W.-S.; Kim, H.-D.; Kim, C.-H.; Park, W.-W.; Park, Y.-H.; Kim, K.-S.; Kim, H.-M.; Kim, D.-S. A tetrodotoxin-producing Vibrio strain, LM-1, from thepuffer fish Fugu vermicularis radiatus. Appl. Environ. Microbiol., 2000, 66, 1698-1701. 
65. Yang, G.; Xu, J.; Liang, S.; Ren, D.; Yan, X.; Bao, B. A novel TTX-producing Aeromonas isolated from the ovary of Takifugu obscurus. Toxicon, 2010, 56, 324-329.

66. Cheng, C.A.; Hwang, D.F.; Tsai, Y.H.; Chen, H.C.; Jeng, S.S.; Noguchi, T.; Ohwada, K.; Hasimoto, K. Microflora and tetrodotoxin-producing bacteria in a gastropod, Niotha clathrata. Food Chem. Toxicol., 1995, 33, 929-934.

67. Brodie III, E.D.; Brodie, Jr. E.D. Evolutionary response of predators to dangerous prey reduction of toxicity of newts and resistance of garter snakes in island populations. Evolution, 1991, 45, 221-224.

68. Brodie III, E.D.; Feldman, C.R.; Hanifin, C.T.; Motychak, J.E.; Mulcahy, D.G.; Williams, B.L.; Brodie Jr., E.D. Parallel arms race between garter snakes and newts involving tetrodotoxin as the phenotypic interface of coevolution. J. Chem. Ecol., 2005, 31, 343-356.

69. Feldman, C.R.; Brodie Jr.; E.D., Brodie III, E.D., Prender, M.E. The evolutionary origins of beneficial alleles during the repeated adaptation of garter snakes to deadly prey. 2009, Proc. Nat. Acad. Sci. USA 106, 13415-13420.

70. Hagen, N.A.; Fisher, K.M.; Lapointe, B.; du Souich, P.; Chary, S.; Moulin, D.; Sellers, E.; Ngoc, A.H.; Canadian Tetrodotoxin Study Group. An open-label, multi-dose efficacy and safety study of intramuscular tetrodotoxin in patients with severe cancer-related pain. J. Pain Symptom Manag., 2007, 34, 171-182.

71. Kao, C.Y. Tetrodotoxin, saxitoxin and their significance in the study of excitation phenomena. Pharmacol Rev., 1966, 18, 997 - 1049. 
72. Xu, Q.H.; Huang, K.; Gao, L.S.; Zhang, H., Rong, K.T. Toxicity of tetrodotoxin towards mice and rabbits. J. Hyg. Res. (Chinese name: Weishen Yanjiu), 2003, 32, 371 - 374.

73. Benzer, T. Toxicity, tetrodotoxin. Retrieved from http://www.emedicine. com/emerg/topic576.htm. 2004.

74. Khor, S.; Wood, S.A.; Salvitti, L.; Taylor, D.I.; Adamson, J.; McNabb, P.; Cary, S.C. Investigating Diet as the Source of Tetrodotoxin in Pleurobranchaea maculata. Marine Drugs, 2014, 12(1), 1-16.

75. Kawatsu, K.; Hamano, Y.; Yoda, T.; Terano, Y.; Shibata, T. Rapid and highly sensitive enzyme immunoassay for quantitative determination of tetrodotoxin. Jpn. J. Med. Sci. Biol., 1997, 50, 133-150.

76. Yamamoto, S.; Yoshimura, M.; Iwata, S.; Matsuura, T.; Shin, M.C.; Yamaga, T., Ito, Y.; Akaike, N. Comparative study on the actions of toxin extracts from two different puffer fishes on I (Na) and respiratory NM transmission in the rat. Fukuoka igaku zasshi Hukuoka acta medica, 2010, $101(8), 173-181$.

77. Williams, B. L.; Brodie Jr, E. D.; Brodie III, E. D. A resistant predator and its toxic prey: persistence of newt toxin leads to poisonous (not venomous) snakes. Journal of chemical ecology, 2004, 30 (10), 1901-1919.

78. Hanifin, C. T. The chemical and evolutionary ecology of tetrodotoxin (TTX) toxicity in terrestrial vertebrates. Marine Drugs, 2010, 8 (3), 577-593.

79. Zimmer, R. K.; Ferrer, R. P. Neuroecology, Chemical Defense, and the Keystone Species Concept. The Biological Bulletin, 2007. 213: 208-225 
80. Yang, G.; Bao, B.; Peatman, E.; Li, H.; Huang, L.; Ren, D. Analysis of the composition of the bacterial community in puffer fish Takifugu obscurus. Aquaculture, 2007, 262 (2-4), 183191.

81. Penzotti, J.L.; Fozzard, H.A.; Lipkind, G.M., Dudley, S.C. Differences in saxitoxin and tetrodotoxin binding revealed by mutagenesis of the $\mathrm{Na}^{+}$channel outer vestibule, Biophys. J., 1998, 75, 2647-2657.

82. El-Dayem, S. M. A.; Fouda, F. M.; Ali, E. H. A.; Motelp, B. A. A. El. The antitumor effects of tetrodotoxin and/or doxorubicin on Ehrlich ascites carcinoma-bearing female mice. Toxicology and Industrial Health, 2013, 29 (5), 404-17.

83. Fernández-Ortega, J. F.; Morales-de los Santos, J. M., Herrera-Gutiérrez, M. E.; FernándezSánchez, V., Rodríguez Loureo, P.; Rancaño, A. A., Téllez-Andrade, A. Seafood intoxication by tetrodotoxin: first case in Europe. The Journal of Emergency Medicine, 2010, 39 (5), 612-7.

84. Food and Drug Administration (FDA). Import Alert 16-20. Retrieved from http://www.accessdata.fda.gov/cms_ia/importalert_37.html, 2014.

85. Mohd Nor Azman, A.; Wan Norhana, M. N. Detection of tetrodotoxin and saxitoxin in dried salted yellow puffer fish (Xenopterus naritus) eggs from Satok Market, Kuching, Sarawak. International Food Research Journal, 2013, 20 (5), 2963-2966.

86. Ministry of Health and Welfare. Japan Standard Methods of Analysis in Food Safety Regulation (Chemistry), 1991, (pp. 296-300). Tokyo.

87. Bentur, Y.; Ashkar, J.; Lurie, Y.; Levy, Y.; Azzam, Z.S.; Litmanovich, M.; Eisenman, A. Lessepsian migration and tetrodotoxin poisoning due to Lagocephalus sceleratus in the eastern 
Mediterranean. Toxicon: Official Journal of the International Society on Toxinology, 2008, 52(8), 964-8.

88. Islam, Q.T.; Razzak, M.A.; Islam, M.A.; Bari, M.I., Basher, A.; Chowdhury, F.R.; Mebs, D. Puffer fish poisoning in Bangladesh: clinical and toxicological results from large outbreaks in 2008. Transactions of the Royal Society of Tropical Medicine and Hygiene, 2011, 105(2), 7480.

89. Lin, Wen-Feng; Hwang, Deng-Fwu. Analysis of Poisoning Cases, Monitoring and Risk Warning for marine Toxins (TTX, PSP and CTXs) in Taiwan. Journal of Food \& Drug Analysis, 2012, 20, 764-771.

90. Yong, Y.S.; Quek, L.S.; Lim, E.K.; Ngo, A. A case report of puffer fish poisoning in Singapore. Case Reports in Medicine, 2013, 206971.

91. Lau, F.L., Wong, C.K.; Yip, S. H. Puffer fish poisoning. Journal of Accident \& Emergency Medicine, 1995, 12 (3), 214-5.

92. Centers for Disease Control and Prevention (CDC). Tetrodotoxin poisoning associated with eating puffer fish transported from Japan-California, 1996. MMWR. Morbidity and Mortality Weekly Report, 1996, 45 (19), 389-91.

93. Ababou, A.; Mosadik, A.; Squali, J.; Fikri, K. ; Lazreq, C.; Sbihi, A. Intoxication par le poisson coffre. Annales Françaises d'Anesthésie et de Réanimation, 2000, 19(3), 188-190.

94. Ravaonindrina N.; Andriamaso, T.H.; Rasolofonirina, N. Intoxication après consommation de poisson globe à Madagascar : à propos de 4 cas. Archives de l'Institut Pasteur de Madagascar, 
2001.

Retrieved

March

03 ,

2014 ,

from

http://indexmedicus.afro.who.int/iah/fulltext/intoxication.pdf

95. Isbister, G.K.; Son, J.; Wang, F.; Maclean, C. J.; Lin, C.S.-Y.; Ujma, J.; Kiernan, M.C. Puffer fish poisoning: a potentially life-threatening condition. The Medical Journal of Australia, 2002, 177 (11-12), 650-3.

96. How, C.-K.; Chern, C.-H.; Huang, Y.-C.; Wang, L.-M.; Lee, C.-H. Tetrodotoxin poisoning. The American Journal of Emergency Medicine, 2003, 21 (1), 51-4.

97. Ahasan, H. A. M. N.; Mamun, A. A.; Karim, S. R.; Bakar, M. A.; Gazi, E. A.; Bala, C. S. Paralytic Complications of Puffer Fish (Tetrodotoxin) Poisoning. Singapore Medical Journal, 2004, 45 (2), 73-73.

98. Chowdhury, F.R.; Ahasan, H. A. M. N.; Al Mamun, A.; Rashid, A. K. M. M.; Al Mahboob, A. Puffer fish (Tetrodotoxin) poisoning: an analysis and outcome of six cases. Tropical Doctor, 2007, 37 (4), 263-4.

99. Nakashima, R.; Nakata, Y., Kameoka, M., Hayashi, N.; Watanabe, K.; Yagi, K. [Case of tetrodotoxin intoxication in a uremic patient]. Chūdoku Kenkyū: Chūdoku Kenkyūkai Jun Kikanshi, The Japanese Journal of Toxicology, 2007, 20 (2), 141-5.

100. Chowdhury, F.R.; Nazmul Ahasan, H. A. M., Mamunur Rashid, A. K. M.; Al Mamun, A.; Khaliduzzaman, S. M. Tetrodotoxin poisoning: a clinical analysis, role of neostigmine and shortterm outcome of 53 cases. Singapore Medical Journal, 2007, 48, 830-3.

101. Commission Regulation (EC) $N^{o} 854 / 2004$. Laying down specific rules for the organisation of official controls on products of animal origin intended for human consumption. 2004. 
102. De Sousa, M.L. Occurrence of Tetrodotoxin Producing Bacteria on Marine Gastropods of the Northern Coast of Portugal. Instituto de Ciências Biomédicas de Abel Salazar da Universidade do Porto. 2011. Retrieved from http://repositorioaberto.up.pt/bitstream/10216/56918/2/Tese Marcos Final.pdf

103. Hotta., M. The sustainable contribution of fisheries to food security in the Asia and Pacific region: regional synthesis. In: Sustainable contribution of fisheries to food security. Food and Agriculture Organization of the United Nations, Bangkok, Thailand. 2000.

104. Position of the American Dietetic Association: Food and water safety. Journal of the American Dietetic Association, 2003, 103 (9), 1203-1218.

105. Anonymous. FDA consumer health information - fish hazards and controls: More than a fish story. CHAPTER 6: Natural Toxins. PR Newswire. 2011. Retrieved October 09, 2013, from http://www.fda.gov/downloads/food/guidanceregulation/ucm252395.pdf

106. Chamandi, S.C.; Kallab, K.; Mattar, H.; Nader, E. Human poisoning after ingestion of puffer fish caught from Mediterranean Sea. Middle East Journal of Anesthesiology, 2009, 20 (2), $285-8$. 
Table 1. Episodes of intoxications and deaths related to puffer-fish consumption in world by different authors.

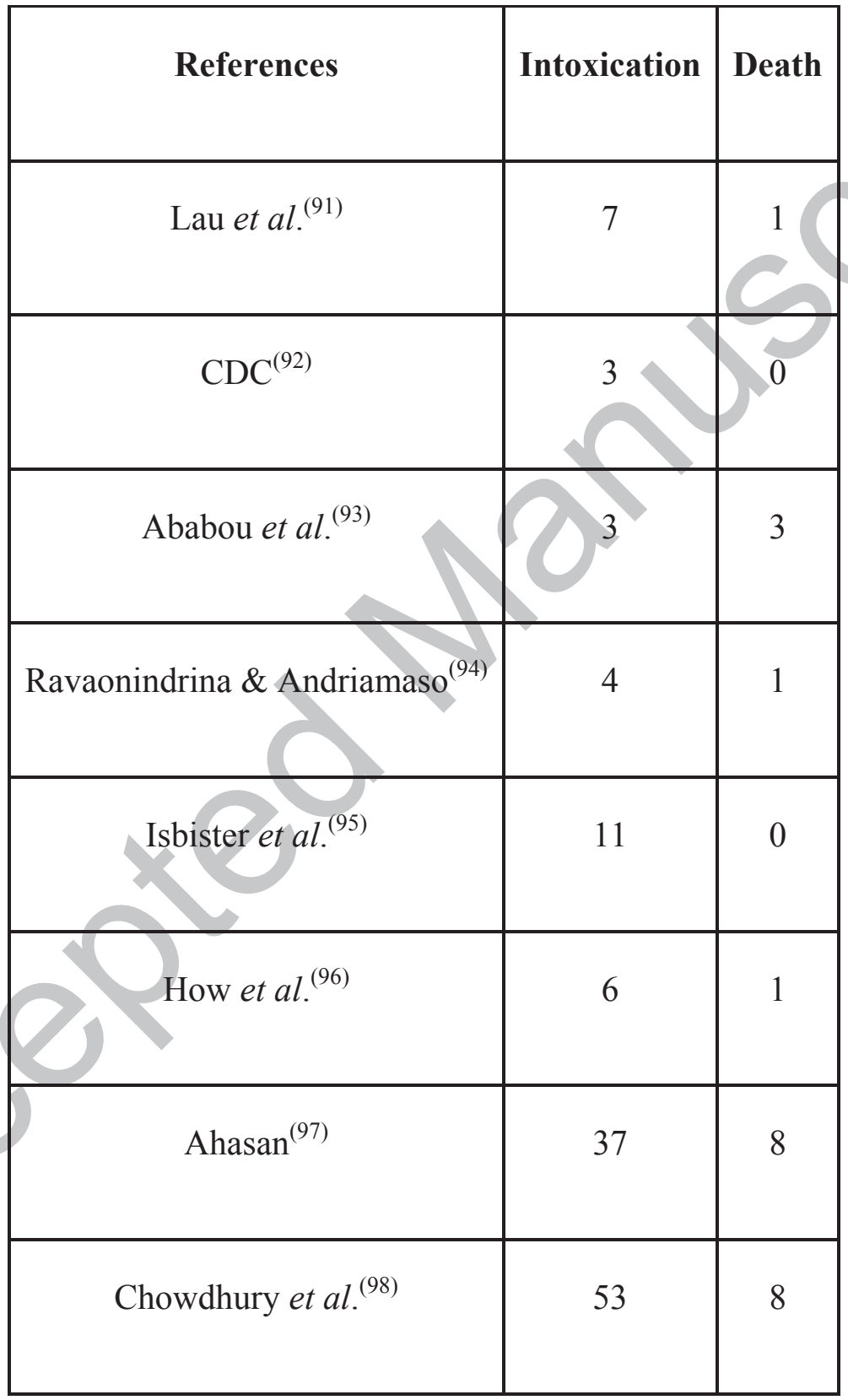




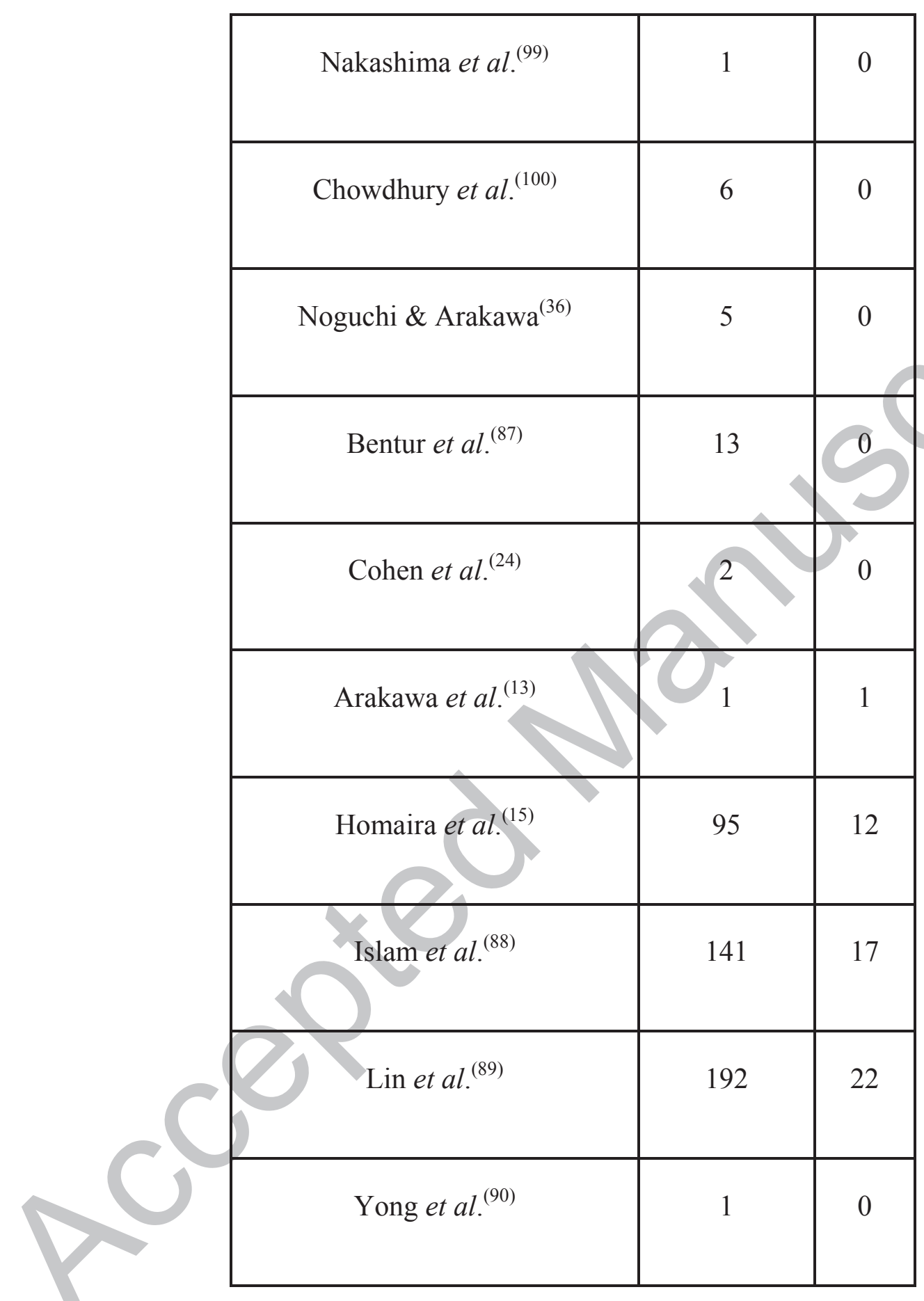


Figure 1. Chemical structure of TTX ${ }^{(45,47)}$.

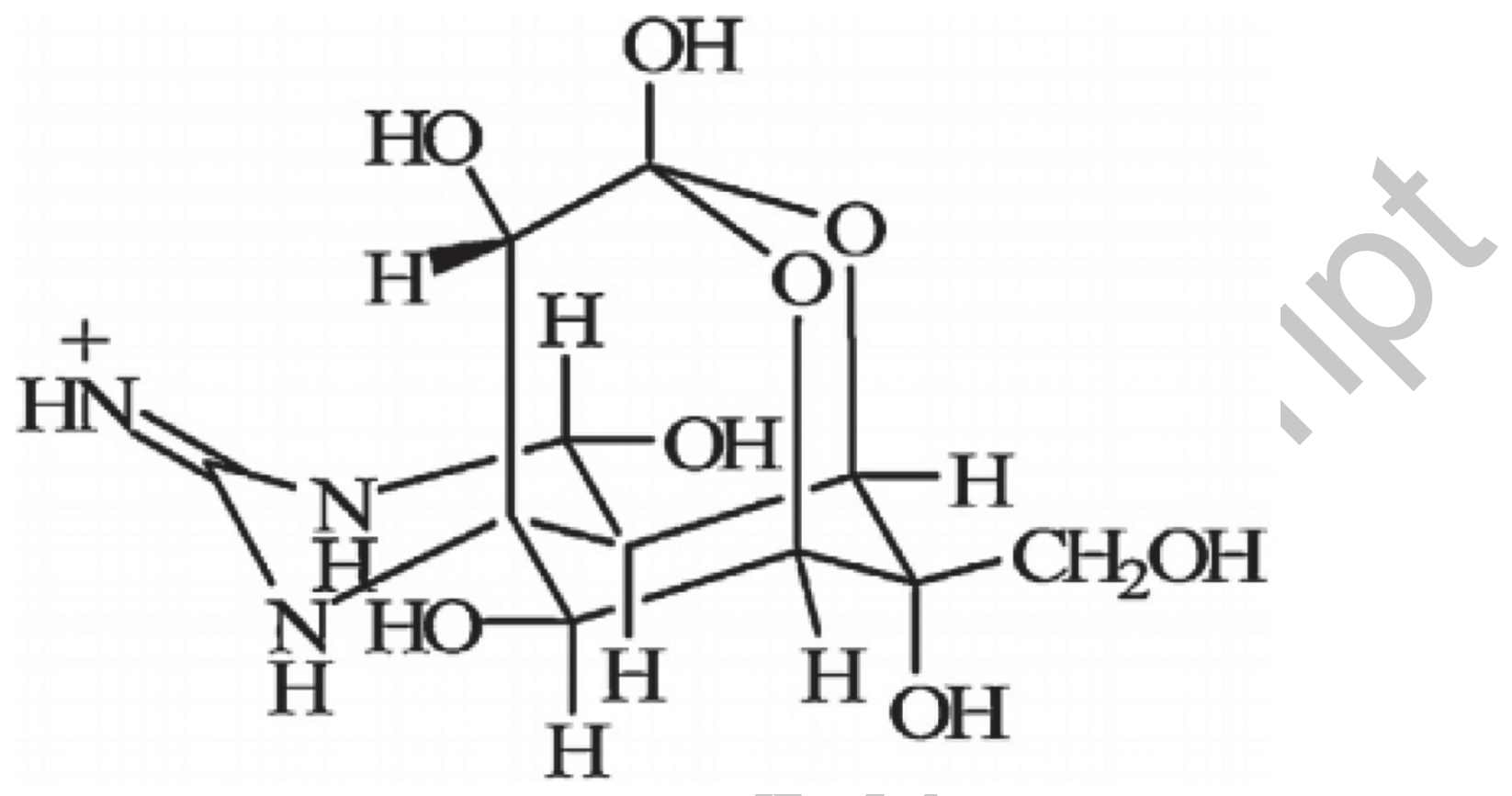


Figure 2. Chemical synthesis of TTX from glucose ${ }^{(49)}(R=\mathrm{MOM})$.
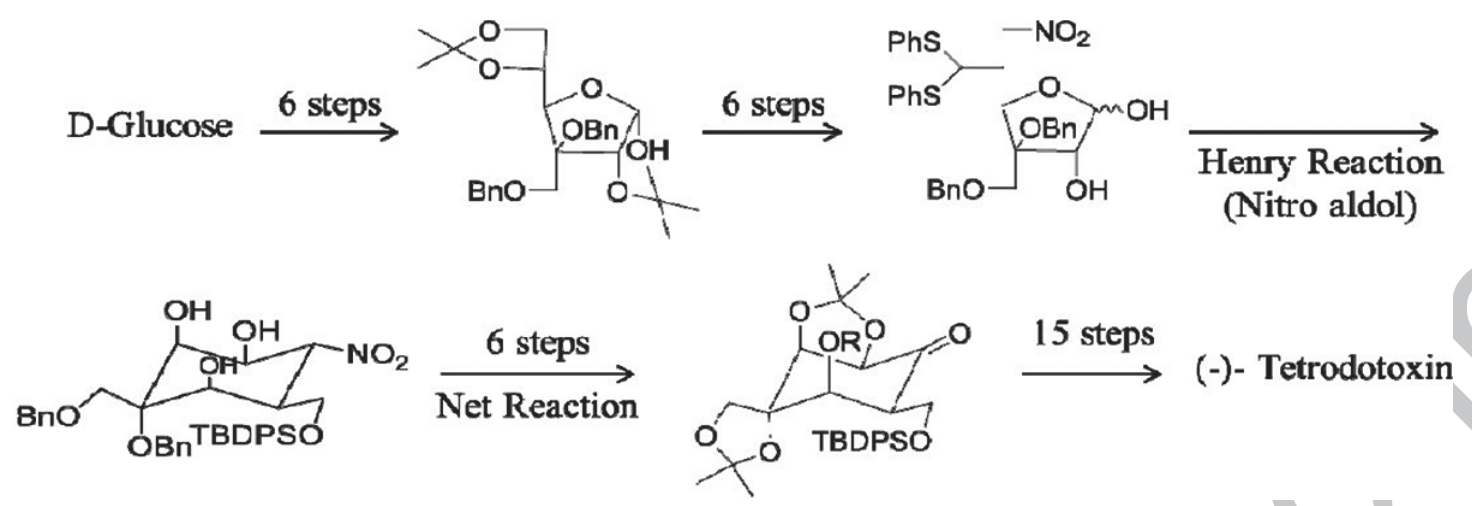
Figure 3. Proposed biosynthesis of TTX from arginine ${ }^{(53,55)}$.

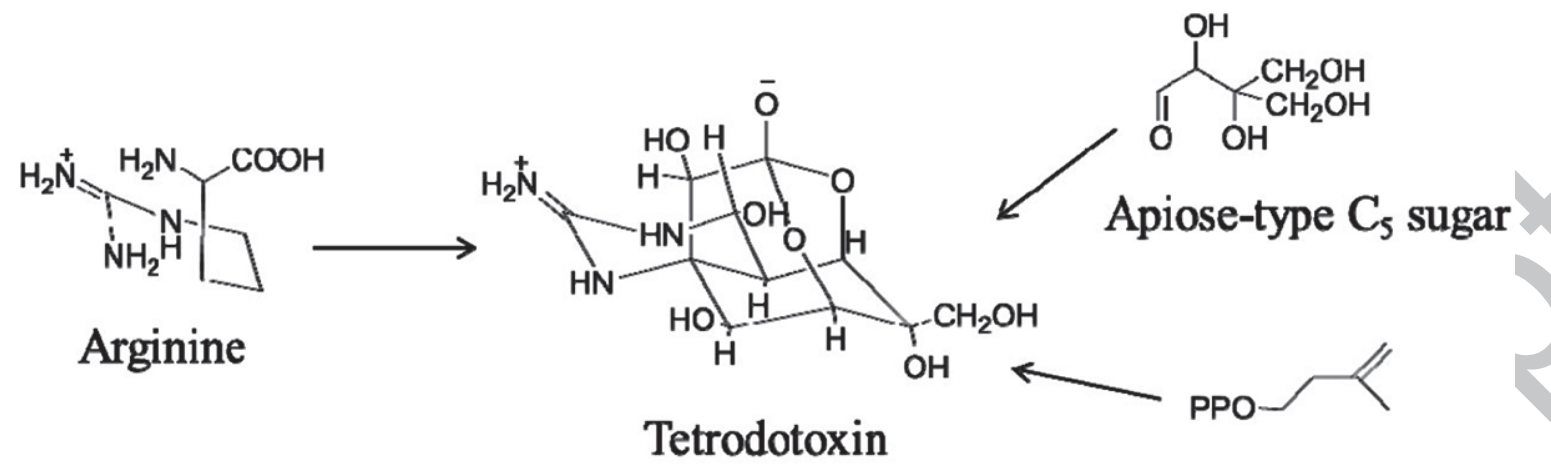

Isopentenyl-PP 
Figure 4. Proposed mechanism of TTX accumulation in marine animals ${ }^{(60)}$.

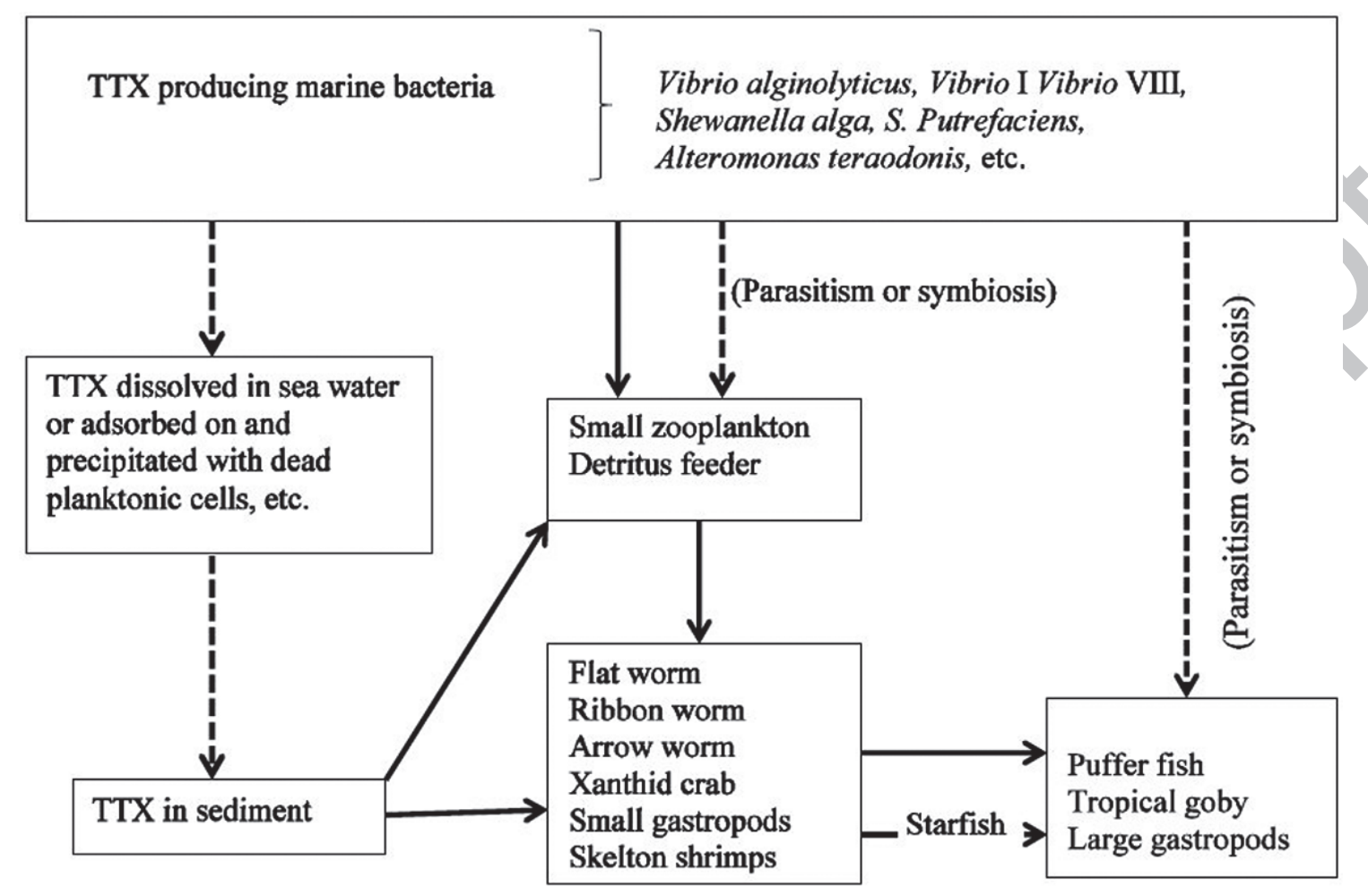

Food chain $\longrightarrow$

Parasitism; Symbiosis; Descomposition ---------------> 
Figure 5. Regions affected by puffer-fish poisoning worldwide.

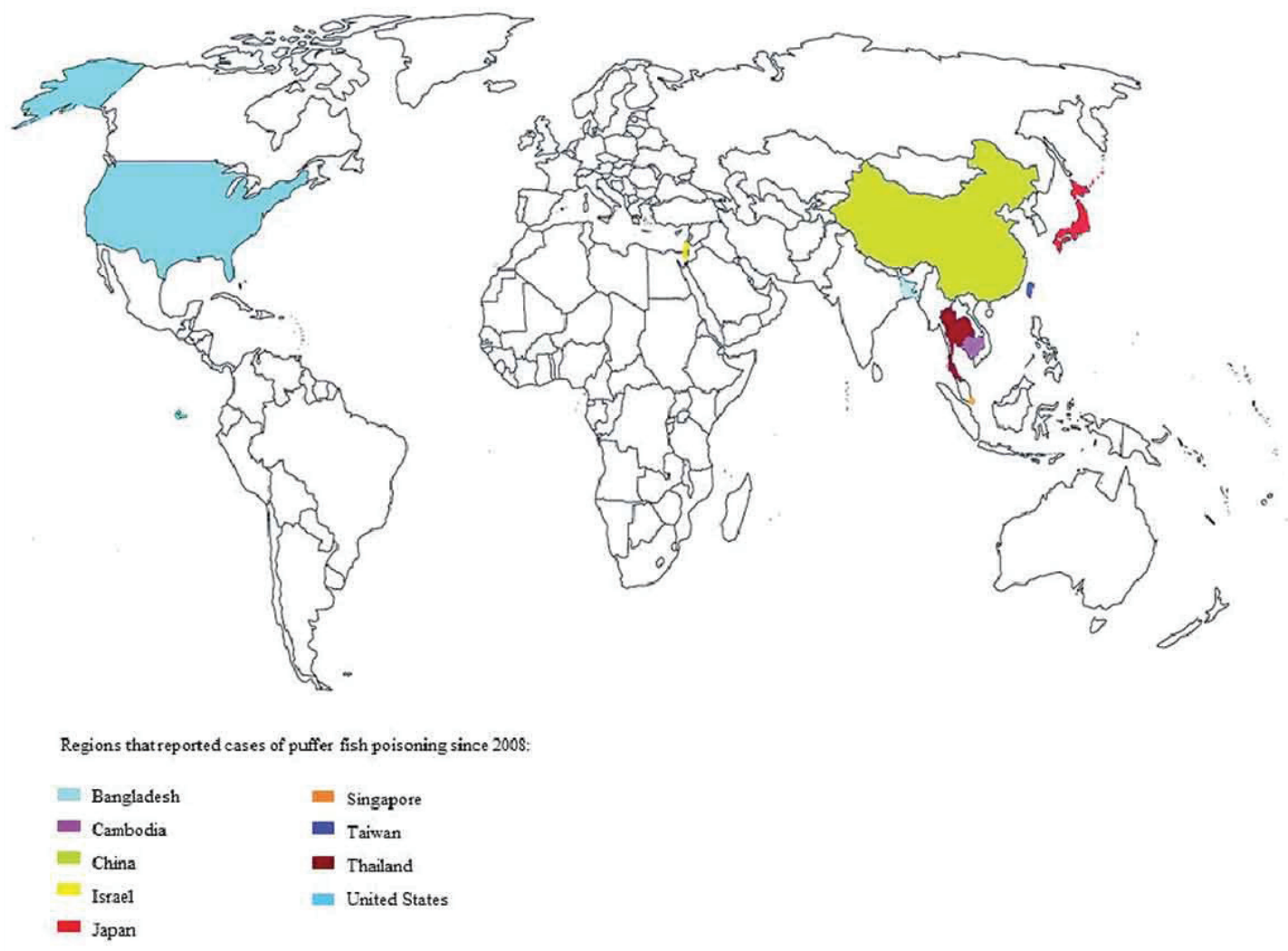

